\title{
Choice modelling for participation in milk marketing channels: Evidence from Punjab, India
}

\author{
Nidhi Singhal ${ }^{1}$, Harjit Kaur ${ }^{1}$, Pampa Mukherjee ${ }^{2}$ and Santanu Basu ${ }^{1,3}$
}

Received: 10 February 2020 / Accepted: 15 May 2020 / Published online: 12 July 2020

(C) Indian Dairy Association (India) 2020

\begin{abstract}
Over the last few decades India has witnessed tremendous growth in the dairy sector giving varied market opportunities to the milk producers. There have been growing concerns regarding exclusion of the lower castes and small holder producers from organised milk marketing channels. In this context, the paper studies the choice of milk marketing channel in relation to the demographic variables using a set of household level data from the districts of Ludhiana and Moga districts in Malwa region of Punjab. Choice modelling has been done using Bivariate Probit Model and the econometric model has been operationalized using software R. To overcome selection bias, a two-step analysis is undertaken to explain participation in liquid milk markets and conditioned on that is the choice of milk marketing channel. The study found that Buffalo is the preferred milch animal in this area. The region is dominated by organised milk marketing channel with $69 \%$ households selling milk to the organised channel. The study concludes that social barriers which are manifested by caste of the household hamper the capability of the SC households to participate in the organised milk marketing channel.
\end{abstract}

Keywords: Bivariate probit model, Informal marketing channel, Organised marketing channel

${ }^{1}$ Dr. S.S. Bhatnagar University Institute of Chemical Engineering \& Technology, Panjab University, Chandigarh, India

${ }^{2}$ Department of Political Science, Panjab University, Chandigarh

${ }^{3}$ Department of Molecular Sciences, Swedish University of Agricultural Sciences, P.O. Box 7015, SE-750 07, Uppsala, Sweden

Nidhi Singhal $(\square)$

Dr. S.S. Bhatnagar University Institute of Chemical Engineering \& Technology, Panjab University, Chandigarh, India

Email: nidhisinghal.25@gmail.com; Phone 8556962411

\section{Introduction}

From the shortage of milk in the country at the time of independence (1947), India has since 1998 emerged as a top ranking milk producing country in the world. At present India produces almost $20 \%$ of the total liquid milk produced in the world. According to GoI (2017), the country produced 165.4 million tonnes in 2016-17. Milk group is the biggest source of income generation within the agricultural sector with an annual output value of Rs. 416611 crore, which is nearer to the combined value of cereals and pulses in the same period (CSO 2017). Milk and milk products are also an important source of calorie and protein intake for the significant vegetarian Indian population. Between 2000-01 and 2011-12, the share of milk and milk products in the monthly per capita food expenditure increased from $15.4 \%$ to $18.7 \%$ in rural areas and from $18.9 \%$ to $20.3 \%$ in urban areas (GoI 2001; GoI 2012). India is thus witnessing tremendous growth in the dairy sector due to rise in market demand, expanding urban population, changing lifestyles, and increasing health consciousness (Kumar et al. 2014). Due to formalization of Indian dairy sector, food safety regulations are becoming increasingly important in the dairy sector in India. These changes make market access more difficult for the informal sector and encourage a higher involvement of the private sector in organized milk marketing. All these factors have contributed to creating a market interest for the newer players in the dairy sector and are catalytic in expansion of business operations of traditional cooperatives and companies already in dairy business.

Since past three decades, dairy sector in the country transitioned from protectionism to liberalization which led to the growth of the private milk processors (Birthal et al. 2017). The state of Punjab, the domain of our study and one of the most dairydeveloped states in India too witnessed this trend. (Appendix I). By 2016-17, the milk processing capacity in the state increased to more than 80 lakh litres per day by 2016-17 from 42 lakh litres per day at the time of operation flood. A major part of the total milk processing capacity, around $75 \%$ belongs to the private sector.

Consequently, the newly emerged dairy ecosystem is providing more avenues to the farmers for selling milk at the village level. With multiple players in the field, dairy sector is now witnessing 
enormous complexity in the dairy supply chain in rural India. In this context, it is imperative to understand how the demographic factors influence the households' choice for milk marketing channel at the village level.

More specifically, the research questions is: "What are the demographic determinants of milk producing households' participation in organized/ informal marketing channels in the Malwa region of Punjab?"

In India, specifically Punjab, there are few studies which investigated the factors which impact the choice of milk marketing channels at the household level. Some studies provide anecdotal evidence of smallholder participation in organized marketing channels in Punjab (Vandeplas et al. 2013; Sharma 2015; Birthal et al. 2017; Brar et al. 2018). These studies are spread over a wider geographical area and hence miss out on the local nuances. The current literature also captures the impact of both demographic variables and village-specific variables such as distance from the urban centres, road density, etc. on the choice of milk marketing channel. Most of the current literature uses a single step multinomial and binomial probit (Vandeplas et al. 2013) and multinomial logit (Sharma 2015; Birthal et al. 2017) to understand the choice of milk marketing channel. None of these studies incorporate the selection bias in the choice of milk marketing channel. The selection bias becomes important because not all households who have a milch animal, participate in liquid milk markets. Staal et al. (2006) however has carried out a two-step analysis to explain milk market participation and conditioned on that, milk outlet choice in Gujarat.

The present study restricts itself to two important districts in central plains (Malwa region) of Punjab - namely Ludhiana and Moga. Further, the five villages in these two districts were selected such that they have similar agricultural and livestock economy, distance from the urban centre, presence of organized and informal milk marketing channel, number of milk collection centres. This study uses a bivariate probit model - with a selection equation to determine the participation of dairy farmers in liquid milk markets.

\section{Materials and Methods}

The major objective of the research was to understand the determinants of marketing channel choice for milk producing households in the five selected villages in Ludhiana and Moga district of Punjab which have a well-developed milk economy. A two-stage sampling - purposive sampling followed by stratified random sampling was done to arrive at the sampled households.

In order to control the effect of the various village level characteristics and study the impact of only of demographic characteristics on the choice of milk marketing channel purposive sampling was done at the first stage. Five villages - three from
Ludhiana district and two from Moga district were selected during this first stage after discussions with various stakeholders. The villages selected in the study were such that they do not have a vast regional and infrastructural difference. All the five villages have similar basic physical infrastructure including anganwadis, primary and secondary schools, primary health clinics, government water tanks and reverse osmosis water purification systems at the village level. The main crops produced are rice, wheat, and fodder in all the five villages. All the villages are at a distance less than $20 \mathrm{Km}$ from the district sub-centre. Market for dairying was well developed in all the selected villages. All the villages were similar in terms of presence of organized/formal and informal milk marketing channels.. The different organized players for milk collection present in these villages are indicated in Appendix II.

At the second stage, given the central importance of caste systems in Indian agriculture, caste-based strata were formed, and then systematic random sampling was used in each strata to select the households at the village level. The data for the study was collected in May, June, and July of 2016 - this is the supposedly lean season of dairy animals.

The dairy farmers have a choice to sell the milk through organized marketing channel which includes cooperatives (Milkfed), MNCs (Nestle, Danone etc.) and domestic private processors; or informal marketing channel (mainly milkman) which includes local traders and vendors; or consumer - households. In the sample, most of the members selling milk to the organized sector did not sell milk to the informal sector and vice versa. However, very few members who sold milk to both the channels and exclusively to consumer households were dropped from the data. Finally we arrived at a sample of 214 households from 5 villages, 107 belonged to Schedule Caste (SC), and 107 belonged to general caste.

Explanatory variable includes various demographic characteristics of the household and head of the household. Dairying is an economic activity which requires two basic assets - land for fodder/grazing and labour for maintenance/upkeep of the dairy animals. Accordingly, the first two variables are agricultural land owned by the household and the number of family members, which is a proxy for labour. Caste of the household signifies social and economic hierarchical position of the household in the rural areas and is included as the third variable in the study. Since the census-2011 does not include OBC/BC as one of the castes, so the study categorizes caste as General and SC only. Since the study focuses on number of milch animals and participation of households in the organized milk marketing channel, the number of cattle and buffaloes are also included as variables. The characteristics specific to the head of the household which are included in the study are - gender, age and education of the head of the household. Dairying is a labour-intensive occupation with a large participation of females in it. Thus, it is important to understand the impact of gender of the household 
head on number of milch animals and participation in organized milk marketing channels. With more youth being educated and with more than $65 \%$ of Indian population below the age of 35 years, it will also be interesting to understand the impact of age and education on participation of households in organized milk marketing channels. The variables used in the study are detailed in table 1.

\section{Econometric model and estimation procedure}

The choice of milk marketing channel is a selection process which is either buyer-driven or a result of self-selection of the seller, i.e. milk producing household or a mix of both (Vandeplas et al. 2013). A buyer chooses a particular milk producing household to work with - the households with a larger asset base can make complementary investments, households with a more number of milch animals can lead to reduced transaction costs for the buyer or a household with smaller number of milch animals may reduce the procurement risk faced by the buyer, etc. Certain observable and non-observable characteristics may lead a milk producing household to sell milk to a particular milk marketing channel. In the paper, we investigate how the probability of supplying milk to a particular marketing channel varies across milk producing household as a function of relevant characteristics of the household. The model has a mix of continuous and discrete dependent variables which are indicative of the socio-economic and demographic characteristics of the households.

To overcome selection bias, a two-step analysis is undertaken to explain participation in liquid milk markets and conditioned on that is the choice of milk marketing channel. The model used in the study is bivariate probit with sample selection, which is equivalent to Heckman's selection model except now we have probit model in selection equation and a probit model in the outcome equation (Greene 2015). The model consists of two components: a probit equation for participation in liquid milk markets and a probit equation for the outcome, i.e. choice of a milk marketing channel which is observed only for the sub-sample.

The household is assumed to select the alternative- whether to participate in liquid milk markets or not, that gives the household maximum utility. The expected utility of selling milk, i.e. participation in liquid milk markets is given by:

$$
U_{i}=\alpha X_{i}+u_{i}
$$

Where ${ }^{\alpha}$ is a vector of unknown parameters; ${ }^{X_{i}}$ is the vector of exogenous values of observation, i.e. household and household head specific characteristics namely - namely Members, Land, Caste, Cattle, Buffaloes, GenderHH, AgeHH, and EducationHH and ${ }^{\mathrm{u}_{\mathrm{i}}}$ is the unobserved random component which is assumed to be jointly normally distributed. We cannot observe the utility, but we know if a household participates in liquid milk markets or $\operatorname{not}^{, Y_{\text {iI }}}$.

$$
Y_{i 1}=\left\{\begin{array}{c}
1 \text { if } U_{i}>0 \\
0 \text { otherwise }
\end{array}\right.
$$

The probit model for participation in liquid milk markets is given by:

$Y_{\mathrm{iI}}=\mathrm{X}_{\mathrm{i} 1} \beta_{1}+\varepsilon_{\mathrm{iI}}$

On similar lines, the probit equation for the choice of milk marketing channel is:

$Y_{i 2}=X_{i 2} \beta_{2}+\varepsilon_{i 2}$

Where $Y_{\mathrm{i} z}$ is a vector of two marketing channel choices namely organised sector and informal sector $(=0$ for organized sector and $=1$ for informal sector) of the $i^{\text {th }}$ dairy farmer. is a vector of household and household head characteristics that together reflect the capacity, risks and incentives to supply milk to a particular marketing channel.

Where, and are the unobserved components. It is likely that these components are correlated across individuals. is observed only when $=1$ and is defined only on sub population for which $=1$. These issues lead to the problem of selection bias in the study.

There are three types of observation in the sample:

$$
\begin{gathered}
Y_{i 1}=0 \\
Y_{i 1}=1, Y_{i 2}=0 \\
Y_{i 1}=1, Y_{i 2}=1
\end{gathered}
$$

The probability of each of the observation is given by:

$$
\begin{gathered}
\operatorname{Pr}\left(Y_{i 1}=0\right)=\Phi\left(-\beta_{1} x_{i 1}\right) \\
\operatorname{Pr}\left(y_{i 1}=1, y_{i 2}=0\right)=\Phi\left(\beta_{1} x_{i 1}\right)-\Phi_{2}\left(\beta_{1} x_{i 1}, \beta_{2} x_{i 2}, \rho\right) \\
\operatorname{Pr}\left(y_{i 1}=1, y_{i 2}=1\right)=\Phi_{2}\left(\beta_{1} x_{i 1}, \beta_{2} x_{i 2}, \rho\right)
\end{gathered}
$$

Where Ö is the cumulative distribution function (CDF) of the standard normal distribution, is the distribution to estimate bivariate probit models, parameters and are typically estimated by maximum likelihood and is the correlation coefficient. 
For the two-step analysis, in the first step, we use a probit model to understand the milk-producing households' decision to participate in milk markets, which is either a 'Yes' or a 'No'. Inverse mills ratio is calculated in this step and is introduced as an additional explanatory variable in the next step which is a probit model with the dependent variable as the choice of milk marketing channel which can either be organized channel or the informal channel. The marginal effect of each dependent variable is also calculated using the sample mean of all variables.

The procedure is implemented in $\mathrm{R}$ (version 3.5.1) using package "sampleSelection" and marginal effects having been calculated using package "margins".

Appendix I Growth of Milk Processing Sector in Punjab (1989-2017)

\begin{tabular}{|c|c|c|c|c|c|c|c|c|c|}
\hline \multirow[t]{2}{*}{ Year } & \multicolumn{3}{|l|}{ Milk Plants } & \multicolumn{3}{|c|}{ Chilling Centres } & \multicolumn{3}{|c|}{ Capacity ('000 liters per day) } \\
\hline & $\begin{array}{l}\text { Cooperative } \\
\text { Public }\end{array}$ & /Private & $\begin{array}{l}\text { Joint } \\
\text { sector }\end{array}$ & $\begin{array}{l}\text { Cooperative / } \\
\text { Public }\end{array}$ & Private & $\begin{array}{l}\text { Joint } \\
\text { sector }\end{array}$ & $\begin{array}{l}\text { Cooperative } \\
\text { / Public }\end{array}$ & Private & $\begin{array}{l}\text { Joint } \\
\text { sector }\end{array}$ \\
\hline$\overline{1989-90}$ & 11 & 5 & - & 39 & - & - & 1210 & - & 760 \\
\hline 1996-97 & 11 & 17 & - & 32 & - & - & 1585 & 2645 & - \\
\hline $\begin{array}{l}2016-17 \\
\text { a: data } f\end{array}$ & $\begin{array}{l}9 \\
\text { r 2013-14 }\end{array}$ & $65 \mathrm{a}$ & 3 & 49 & - & - & 1975 & 6038 & 500 \\
\hline
\end{tabular}

Source: GoP (1990, 1997, 2017) - Statistical Abstract of Punjab

Appendix II Presence of milk collection centres of various organized players in the selected villages

\begin{tabular}{lllll}
\hline Name of the Village & Danone & Nestle & Verka & Others \\
\hline Bhundri & Yes & Yes & - & Yes \\
KilliChahal & Yes & Yes & - & - \\
KokriKalan & Yes & Yes & Yes & Yes \\
KokriPhula Singh & Yes & Yes & Yes & - \\
SherpurKalan & Yes & Closed recently & Yes & Yes \\
\hline
\end{tabular}

Source: Field Study

Table 1 Explanatory variables used in the study for primary data collection

\begin{tabular}{|c|c|c|}
\hline Symbol & Definition & $\begin{array}{c}\text { Unit of } \\
\text { measurement }\end{array}$ \\
\hline Members & Number of family members in a household. & Number \\
\hline Caste & $\begin{array}{l}\text { Social caste of the household and has been categorized as Schedule } \\
\text { Caste (SC) or General }\end{array}$ & Categorical \\
\hline Buffalo & Total number of adult female buffaloes in the household & Number \\
\hline Milch animals & $\begin{array}{l}\text { Total number of adult female bovine animals in the household. It is } \\
\text { a sum of cattle and buffalo explained above }\end{array}$ & Number \\
\hline GenderHH & $\begin{array}{l}\text { Gender of the head of household and is categorized as male (M) and } \\
\text { female (F) }\end{array}$ & Categorical \\
\hline
\end{tabular}


years. The average herd size is 4.2 animals for General caste households while it is 1.2 for SC households.

From table 2, we observe that there is a positive relationship between asset ownership, i.e. average land holding size and average number of milch animals. A larger land holding size gives easy access to fodder, thus helps in production of surplus milk for sale. As per table 3, average land ownership is higher for the households selling milk to the organized channel, which suggests that organized channel reduces its transaction costs and ensures stability in their operations by working with households with a larger asset base. Average herd size of both categories of farmers - those supplying milk to organized channel as well as informal channel is almost comparable at 7 dairy animals per household.

Contrary to previous studies (Vandeplas et al. 2013; Sharma 2015) which conclude that smallholders are more likely to participate in milk markets, this study suggests that dairying is equally practiced by smallholder and large holder milk producing households in the districts of Ludhiana and Moga, Punjab. As per table 2, 52\% of the milk-producing households who sell milk have a herd size of less than 5 dairy animals and own $29 \%$ of total dairy animals. Remaining $48 \%$ of the households have a herd size greater than 6 animals, and they own $71 \%$ of total dairy animals.

The number of milch animals are positively correlated with the number of household members. Households which sell milk have more number of members in the family in comparison to those who do not sell milk, wherein additional members act as surplus labor for dairying activities.

As per table 3, 69\% of the households sell milk to the organized channel while the remaining $31 \%$ sell milk to the informal channel. Average number of milch animals and an average number of members are almost comparable for the households selling milk to the two different channels.

Table 2 Demographic data of surveyed households segregated by number of milch animals

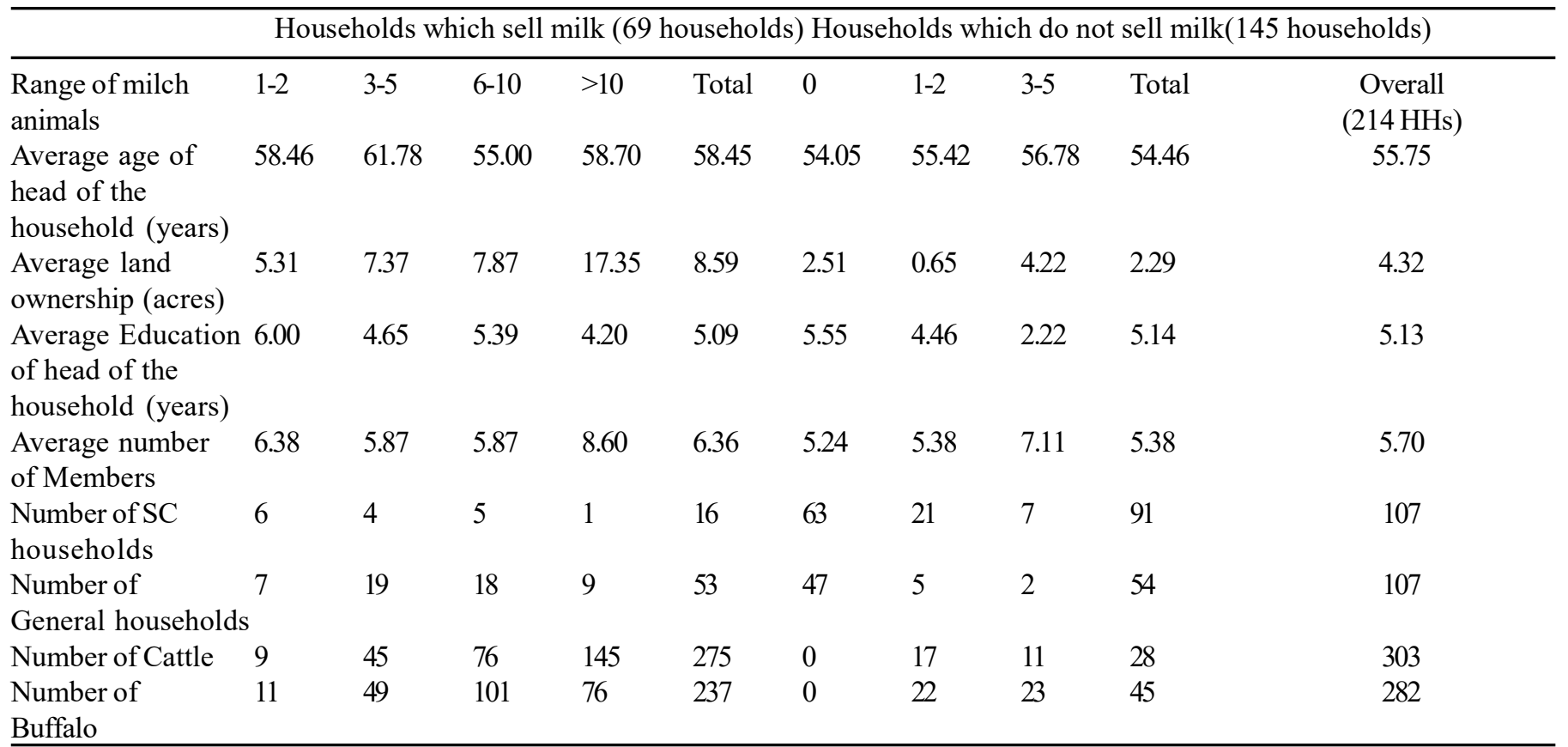

Table 3 Demographic data of households selling milk to different marketing channels

\begin{tabular}{lllllll}
\hline & Organized & \multicolumn{3}{l}{ Informal } \\
\cline { 2 - 6 } & General & SC & Overall & General & SC & Overall \\
\hline Average age of head of the household (years) & 60.40 & 66.50 & 61.17 & 51.45 & 53.10 & 52.24 \\
Average land ownership (acres) & 10.40 & 0.50 & 9.17 & 11.45 & 2.70 & 7.29 \\
Average Education of head of the household (years) & 4.76 & 2.50 & 4.48 & 6.91 & 6.00 & 6.60 \\
Average number of Members & 6.17 & 8.67 & 6.48 & 5.64 & 6.48 \\
Average number of milch animals & 7.74 & 4.33 & 7.35 & 10.45 & 4.60 & 10 \\
Number of households & 42 & 6 & 48 & 11 & 7.10 \\
Average number of Cattle & 4.98 & 0.83 & 4.46 & 3.91 & 1.80 & 21 \\
Average number of Buffalo & 2.76 & 3.50 & 2.85 & 6.55 & 2.80 & 2.90 \\
\hline
\end{tabular}


The plight of the people who are considered at the bottom of the social caste pyramid i.e. scheduled caste (SC) is clearly visible in the descriptive data. The marginalized section face hurdles not just at one level but at multiple levels - starting from asset ownership in terms of land and number of milch animals to opportunity of participation in organized milk marketing channel. Scheduled caste households have a stronger representation in categories with no or few dairy animals. Scheduled caste households are also less likely to sell milk. Only $41 \%$ of scheduled caste households are milk producers out of which only $36 \%$ sell milk. In the sample, $44 \mathrm{SC}$ households own a milch animal, with 17 of them having more than 3 milch animals. However, only 6 of these households are able to engage with the organized milk marketing channel. Thus, most of the SC households are not able to engage with an alternative channel for milk sale. On the other hand, amongst general households, $56 \%$ of the households own an animal out of which $88 \%$ sell milk. Further, most of the SC households sell milk to the informal channel while organized channel is dominated by general caste households. $79 \%$ of milk selling general households sell milk to organized channel while only $37 \%$ of milk selling SC households sell milk to organized channel. As per the field discussions, many $\mathrm{SC}$ households prefer informal channel because of various facilities offered by them such as doorstep collection, the facility of advance payment, better prices especially during the lean season, etc.

Another interesting observation from the data is that milk producing households which sell milk prefer buffaloes over cattle in comparison to those who do not sell milk. The ratio of cattle is to buffaloes is $1.16: 1$ among households which sell milk while it is 1:1.6 among the households which do not sell milk. Also SC households prefer to keep more buffaloes than cattle. Further, households selling milk to the organized sector have $60 \%$ cattle in the total herd; households selling milk to the informal sector

Table 4 Results of the selection equation (probit model for households' participation in milk markets i.e. those households which own a milch animal)

\begin{tabular}{lllllc}
\hline $\begin{array}{l}\text { Col }(1) \\
\text { Independent variables }\end{array}$ & $\begin{array}{c}\text { Col }(2) \\
\text { Estimate }\end{array}$ & $\begin{array}{c}\text { Col }(3) \\
\text { Std. Error }\end{array}$ & $\begin{array}{c}\mathrm{Col}(4) \\
\mathrm{z} \text { value }\end{array}$ & $\begin{array}{c}\mathrm{Col}(5) \\
\operatorname{Pr}(>|z|)\end{array}$ & $\begin{array}{c}\mathrm{Col}(6) \\
\text { Marginal effects }\end{array}$ \\
\hline (Intercept) & -1.14932 & 1.10009 & -1.045 & 0.29613 & -0.006876 \\
Members & -0.03088 & 0.10059 & -0.307 & 0.75882 & -0.008447 \\
Land & -0.03794 & 0.02226 & -1.704 & 0.08830 & -0.3202 \\
CasteSC & -1.21389 & 0.41467 & -2.927 & $0.00342 * *$ & 0.08023 \\
GenderHHM & 0.3627 & 0.49083 & 0.739 & 0.45993 & 0.003406 \\
AgeHH & 0.0153 & 0.01502 & 1.018 & 0.30846 & 0.007735 \\
EduHH & 0.03475 & 0.03792 & 0.916 & 0.35957 & 0.05933 \\
Buffaloes & 0.26652 & 0.09222 & 2.89 & $0.00385 * *$ & 0.09544 \\
Cattle & 0.4287 & 0.15548 & 2.757 & $0.00583 * *$ & \\
\hline
\end{tabular}

Signif. codes: 0 '***’ $0.001^{\prime} * *$ ’ $0.01^{\prime} *{ }^{*} 0.0$ (Dispersion parameter for binomial family taken to be 1)Null deviance: 135.012 on 103 degrees of freedomResidual deviance: 83.461 on 96 degrees of freedomAIC: 101.46 Number of Fisher Scoring iterations: 9 $\mathrm{N}=104 \mathrm{Pr}(>\mathrm{Chi})=2.055 \mathrm{e}-08 * * * \log$ likelihood $=-41.73066(\mathrm{df}=9)$

Table 5 Determinants for informal milk marketing channel

\begin{tabular}{lllllc}
\hline $\begin{array}{l}\text { Col }(1) \\
\begin{array}{l}\text { Independent } \\
\text { variables }\end{array}\end{array}$ & $\begin{array}{l}\text { Col(2) } \\
\text { Estimate }\end{array}$ & $\begin{array}{l}\text { Col(3) } \\
\text { Std. Error }\end{array}$ & $\begin{array}{c}\text { Col(4) } \\
\text { z value }\end{array}$ & $\begin{array}{c}\text { Col }(5) \\
\operatorname{Pr}(>|z|)\end{array}$ & $\begin{array}{c}\text { Col }(6) \\
\text { Marginal } \\
\text { effects }\end{array}$ \\
\hline (Intercept) & -0.57575 & 1.351764 & -0.426 & 0.6702 & -0.01907 \\
Members & -0.07806 & 0.113292 & -0.689 & 0.4908 & -0.001312 \\
Land & -0.00537 & 0.021883 & -0.245 & 0.8062 & 0.4576 \\
CasteSC & 1.59005 & 0.702701 & 2.263 & $0.0236 *$ & 0.1222 \\
GenderHHM & 0.53912 & 0.728976 & 0.74 & 0.4596 & -0.004693 \\
AgeHH & -0.01921 & 0.018348 & -1.047 & 0.2952 & 0.01518 \\
EduHH & 0.062109 & 0.050366 & 1.233 & 0.2175 & -0.0014 \\
Cattle & -0.00573 & 0.038507 & -0.149 & 0.8817 & 0.03289 \\
Buffaloes & 0.134627 & 0.065277 & 2.062 & $0.0392 *$ & -0.02898 \\
IMR1 & -0.11862 & 0.711554 & -0.167 & 0.8676 &
\end{tabular}

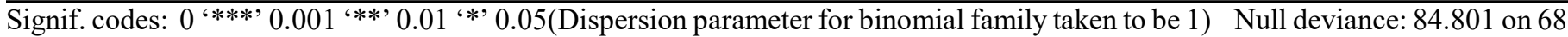
degrees of freedomResidual deviance: 59.061 on 59 degrees of freedomAIC: 79.061 Number of Fisher Scoring iterations: 6 $\mathrm{N}=69 \operatorname{Pr}(>\mathrm{Chi})=0.002253 * *$ Log likelihood $=-29.53073(\mathrm{df}=10)$ 
have $62 \%$ buffaloes in the total herd. Cattle traditionally has been used for producing dung which is used as a fuel and fertilizer, for on-farm operations and finally for milk production. Cattle is also a revered animal in India. However, in current times with advancement in technology and science, the utility of cattle has reduced to being only milk producers. On a commercial scale, rearing of buffaloes is more beneficial to the dairy farmer. Buffaloes offer three main advantages over cattle. Firstly, buffaloes are an efficient converter of low-quality feed and coarse fodders. So they need not be fed with special feeds. Secondly, buffalo milk is higher in fat content compared to cow milk which helps in better price realizations for the farmer, especially if the milk is sold in the informal channel. Pricing of milk is only based on fat content in the informal channel while organized channel includes both fat and SNF percentage in pricing. Finally, there is no social taboo against buffalo slaughter. Households not only find it easy to dispose of male buffalo calves and those buffaloes which have outlived their productive life, but the increasing market of meat export also provides the households with an earning opportunity.

\section{Results of econometric model}

The estimates of the first step, the selection equation for the bivariate probit model (equation (3)) are presented in table 4 . The estimate and average marginal effect of the variable are presented in column (5) and (6) respectively. The results of the probit model bring out that caste, cattle, and buffaloes owned by the household are significant in determining if a household participates in milk markets. Interesting to note here is that caste plays the most significant role. The probability of milk market participation falls by as much as $32 \%$ (on an average) by a mere switch from general to SC. SC households are majorly smallholders and the participation of SC may thus be low because of many impeding factors such as lack of market access, lack of market information, lack of infrastructure and compliance to food safety and quality standards (Bardhana et al. 2012).

Increase in a number of any of the milch animals - cattle or buffalo has a positive effect on participation in milk markets. However, the probability of households' participation in milk markets increases more with an increase in the number of cattle in comparison to the number of buffaloes. Probability of participation in milk markets increases by $5.9 \%$ with a unit increase in the number of buffaloes while it increases by $9.5 \%$ with a unit increase in the number of cattle - be it crossbreed or a local breed. As per the discussion with households, MNCs prefer cow milk over buffalo milk.

Land has a negative influence on milk market participation. If land size increases by one unit, then on average the probability of milk market participation goes down by $0.85 \%$. This implies that households with a larger land holding have an increased focus on primary income-generating activity, i.e. agriculture and their dependence on dairying as a supplementary source of income decreases. Such households retain most the milk for household consumption.

In sync with the findings of Staal et al. (2006), none of the characteristics specific to that of the head of the household are significant. Nonetheless, males with higher education level and higher age are more likely to participate in the milk markets. Contrary to Bardhana et al. (2012) younger male farmers and better-educated farmers are not inclined to milk market participation in the Ludhiana and Moga district of Punjab.

The results of the probit model for marketing channel choice (equation (4)) are presented in table 5. Inverse mills ratio is insignificant, indicating that there is no evidence that selection bias is quantitatively important. Caste and number of buffaloes owned are the two significant factors explaining milk marketing channel choice. Marginal effects indicate that caste of the household followed by the gender of the head of the household has the highest average marginal effects on the choice of milk marketing channel.

The likelihood of supplying milk to the organized sector is considerably lower among the socially disadvantaged households. The probability of selling to an informal player increases by as much as $46 \%$ for an SC household in comparison to general households, which indicates that the informal channel is preferred by the SC households. It implies that either social barriers or economic barriers which the SC category is proxying exist for participation in organized marketing channels, which is consistent with the findings of previous researchers namely, Vandeplas et al. (2013) and Kumar et al. (2011). The possible explanation for this is based on our observation during data collection. From our observation and qualitative discussion with different households, we learned that the SC households and general households are grouped in two different clusters in the villages. Almost all the organized players have their collection centres in the cluster where the general households are located. This makes these collection centres "inaccessible" for the SC households - or at least difficult to access. However, the unorganized/informal players go to each household to collect milk - making it easier for the SC households to sell milk. Also, informal players pay marginally higher price of milk during the lean season in comparison to the organized channel which follows transparent and stable pricing policy.

The number of cattle has no significant influence on the choice of milk marketing channel. The negative coefficient of the number of cattle indicates that those households with more number of cattle tend not to sell milk to the informal sector. However, the marginal effect of cattle is very small. A decrease in a unit number of cattle decreases the probability of supplying milk to the informal sector by only $0.14 \%$ (Table 5 ). 
Also, the number of buffaloes owned by a household has a significant and positive association with participation in informal marketing channels. An increase of 1 unit in the number of buffalo increases the probability of supplying milk to the informal sector by $3.2 \%$ on average. As per qualitative discussions, players in organized channel prefer low-fat cow milk for its conversion into value-added products, while informal channel prefers high fat buffalo milk because most of them sell liquid milk in the urban centres and convert only small quantities into value-added products.

Though insignificant, an increase in the productive assets of the household, i.e., land and members, increases the probability of supplying milk to the organized channel, which is consistent with the findings of Vandeplas et al. (2013). When household heads are male, have a higher education level and lower age group then they tend to supply milk to the informal channel. A change in the gender of the head of the household from female to male increases the probability of supplying milk to the informal sector by $12 \%$.

\section{Policy implications}

Organized milk marketing channel has emerged as a dominant channel for milk procurement in Malwa region of Punjab. However, it has largely excluded the socially disadvantaged strata of population and procures milk largely from the upper caste households in the village. In order to fulfill the aim of inclusive society, it is imperative to include the people at the bottom of the social hierarchy in the procurement by organized milk marketing channels. Organized milk marketing channel prefers to procure cattle milk - can be indigenous or crossbred. Thus, inclusion of cattle in the herds owned by the households will be seen as an opportunity by organized milk marketing channels for milk procurement from such households.

\section{Conclusions}

With the structural transformations taking place in the dairying landscape in the Malwa region in Punjab, the organized channel has become a dominant sector for milk procurement. Almost $70 \%$ of the households sell milk to the organized channel. Though being a dominant sector, it has largely excluded the less endowed and socially disadvantaged SC households. Caste barriers are not only limited to participation in the organized channel, but SC households also have a lesser number of milch animals and are also less likely to sell milk.

Contrary to the trend observed in Punjab, there is an increased preference for buffaloes followed by indigenous cattle in the Ludhiana and Moga districts. Econometric analysis suggests that that participation in milk market rises if the number of cattle and buffalo rises, and there is increased informal market participation if buffalo rises. As buffaloes do well with the coarse feed and also provide high-fat content milk, it is preferred by the informal channels for sale in urban centres. Contrary to it, cow milk is preferred by an organized channel for conversion into products such as packed milk and curd.

\section{Acknowledgments}

We are thankful to Nandi Foundation, Danone Ecosystem Fund and Danone Nutricia for providing the necessary resources to carry out the research. We are also thankful to Centre for Industry Institute Partnership Cell, Panjab University and the students Gaurav Mukundan, Suchetna Bandyopadhyay, Zoravar Rana, Jagjit Kaur, Navdeep Singh, Sachna.

\section{References}

Bardhana D, Sharma M, Saxena R (2012) Market participation behaviour of smallholder dairy farmers in Uttarakhand: A Disaggregated Analysis. Agric Econ Res Rev 25: 243-254

Birthal PS, Chand R, Joshi PK, Saxena R, Rajkhowa P, Khan MT, Khan MA, Chaudhary KR (2017) Formal versus informal: Efficiency, inclusiveness and financing of dairy value chains in Indian Punjab. J Rural Stud 54: 288-303

Brar RS, Kaur I, Singh VP, Kaur N (2018). Factors Affecting Choice of Milk Marketing Channels by Dairy Farmers in Punjab. J Krishi Vigyan 6: 123-129

CSO (2017) National Accounts Statistics 2017. Ministry of Statistics and Programme Implementation. New Delhi.

GoI Government of India (2001) $56^{\text {th }}$ round National Sample Survey of Consumer Expenditure. National Sample Survey Organization. New Delhi

GoI Government of India (2012) $68^{\text {th }}$ round National Sample Survey of Consumer Expenditure. National Sample Survey Organization. New Delhi

GoI Government of India (2017) Basic Animal Husbandry and Fisheries Statistics. Department of Animal Husbandry, Dairying and Fishries, Ministry of Agriculture. New Delhi

GoP Government of Punjab (1990, 1997, 2017) Statistical Abstract Punjab. Economic and Statistical Organization. Chandigarh

Greene WH (2015) Econometric Analysis, 5th ed. Pearson Education, Inc

Kumar A, Joshi PK, Kumar P, Parappurathu S (2014) Trends in the consumption of milk and milk products in India: Implications for self-sufficiency in milk production. Food Secur 6: 719-726

Kumar A, Staal SJ, Singh DK (2011) Smallholder dairy farmers' access to modern milk marketing chains in India. Agric Econ Res Rev 24: 243-253

Sharma VP (2015) Determinants of small milk producers' participation in organized dairy value chains: Evidence from India. Agric Econ Res Rev 28: 247-261

Staal SJ, Baltenweck I, Njoroge L, Patil, BR, Ibrahim MNM, Kariuki E (2006) Smallholder dairy farmer access to alternative milk market channels in Gujarat. Contributed paper at the 26th conference of the International Association of Agricultural Economists, Brisbane, Australia, 12-18 August 2006. Nairobi: ILRI

Vandeplas A, Minten B, Swinnen J (2013) Multinationals vs. cooperatives: The income and efficiency effects of supply chain governance in India. J Agric Econ 64: 217-244 